九州大学学術情報リポジトリ

Kyushu University Institutional Repository

\title{
BIONOMIC NOTES ON THE SOCIAL HALICTINE BEE LASIOGLOSSUM AFFINE (HYMENOPTERA, HALICTIDAE)
}

Sakagami, Shoichi

Hirashima, Yoshihiro

Maeta, Yasuo

Matsumura, Takeshi

https://doi.org/10.5109/2427

出版情報: ESAKIA. 19，pp.161-176，1982-11-25. Entomological Laboratory，Faculty of Agriculture, Kyushu University

バージョン：

権利関係 : 


\title{
BIONOMIC NOTES ON THE SOCIAL HALICTINE BEE LASIOGLOSSUM AFFINE

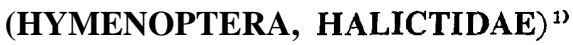

\author{
Shôtchi F . Sakagami ${ }^{2)}$, YoshihiRo Hirashima ${ }^{3)}$, \\ YASUO MAETA ${ }^{4)}$ and TAKeshi MATSUMURA ${ }^{5)}$
}

\begin{abstract}
Bionomics of the halictine bee Lasioglossum(Evylaeus)affine (Smith) was traced based on nest data taken in Fukuoka, periodical adult collecting in Morioka and inferences from the bionomics of related species, especially, L. (E.) duplex (Dalla Torre). L. affine is polytrophic and social, having two discrete brood rearing periods, $\mathrm{P}_{1}$ (solitary or polygynous phase) and $\mathrm{P}_{2}$ (eusocial phase). Both $\mathrm{P}_{1}$ and $\mathrm{P}_{2}$ appear about 1.5 months later in Morioka than in Fukuoka. Queens and workers considerably overlap in size, with the average difference $5.8 \%$ in Morioka. Brood cells form a horizontal and unilateral comb, which is surrounded with a cavity and communicates with the main burrow usually by means of lateroid as in L. duplex.
\end{abstract}

By their diversity of life cycles involving both solitary and social forms, the halictine bees are one of the most promising groups for the study of social evolution in Hymenoptera (Michener, 1974 ; Sakagami, 1974). But the number of species, whose life cycle were well studied, is still insufficient in comparison with the enormous number of the species included in Halictinae, possibly exceeding 2,000 .

The present paper deals with some bionomic observations on Lasioglossum (Evylaeus) affine (Smith, 1853), distributed in Japan, Taiwan, Korea and China (Hirashima, 1957 ; Ebmer, 1978 b). A nest aggregation of this species was discovered by one of us (Y. H.) in Fukuoka, S. Japan. Twelve nests (Figs. 4-15) were excavated in 1958 and 1959. But the nesting site was destroyed before starting closer studies. Relative age and reproductive conditions of females obtained

1) Contribution from the Entomological Laboratory, Faculty of Agriculture, Kyushu University, Fukuoka (Ser. 3, No. 120).

2) Institute of Low Temperature Science, Hokkaido University, Sapporo 060, Japan.

3) Entomological Laboratory, Faculty of Agriculture, Kyushu University, Fukuoka 812, Japan.

4) Laboratorv of Insect Management, Faculty of Agriculture, Shimane University, Matsue 690, Japan.

5) National Grassland Research Institute, Nishinasuno 329-27, Japan. 
from the examined nests were not studied, and the whole results have remained unpublished except for a brief note on the defecating habit of full-grown larvae (Hirashima, 1960). In 1976, two of us (Y. M. and T. M.) made a periodical wild bee survey near Morioka, N. Japan, using the methods developed by Sakagami and Fukuda (1973) and Sakagami et al. (1974). From the obtained collection, L.affine was separated and size and relative age of each female were studied by S. F. S., but their ovarian and spermathecal conditions could not be determined. Although these available data are not yet sufficient to give a precise picture of the life cycle of this species, an approximate sketch is presented in part inferred from information obtained for other related species (compiled by Sakagami, op. cit.), particularly L.(E.) duplex (Dalla Torre) (Sakagami, 1977 ; Sakagami and Hayashida, 1958, 1960, 1961, 1968) and L.(E.) calceatum (Scopoli) (Sakagami and Munakata, 1972). Before going further, it should be mentioned that the most advanced social halictine species in the Palaearctics are found in the carinate group (propodeum well carinate dorsally) of the subgenus Evylaeus Robertson (1902), to which L.affine belongs, and that the so far studied social species of this group are all characterized by discrete production of broods, that is, the occurrence of two or more separate brood rearing periods (Knerer and Plateaux-Quénu, 1967 a ; Sakagami, 1974; Sakagami and Hayashida, 1968).

\section{Life cycle}

In Fukuoka nests were excavated in May, June and July. Table 1 depicts seasonal change of the composition of immatures found in these nests (henceforth coded $N_{1}-N_{12}$ ). A glance at the table it is obvious that foraging activity appears from May to July. From the presented data alone, it is difficult to determine whether brood rearing is continuous or discrete. But examination of nest structures (Figs. 4-15) favors the occurrence of two separate periods, one in $\mathrm{May}\left(\mathrm{N}_{1}-\mathrm{N}_{7}\right)$ and the other from late June to July $\left(\mathrm{N}_{8}-\mathrm{N}_{12}\right)$. In $\mathrm{N}_{1}-\mathrm{N}_{7}$ depths $(\mathrm{cm})$ of bottoms of cell clusters were $8\left(\mathrm{~N}_{6}\right.$, Cluster 1$), 9.2\left(\mathrm{~N}_{3}\right), 10.6$

Table 1. Seasonal change of composition of immatures in nests of L. affine studied in Fukuoka.

\begin{tabular}{|c|c|c|c|c|c|c|c|c|c|c|}
\hline \multirow{2}{*}{ Nest code } & \multirow{2}{*}{$\begin{array}{c}\text { Date of } \\
\text { excavation }\end{array}$} & \multicolumn{9}{|c|}{ No. of immatures confirmed } \\
\hline & & I" & II" & III" & IV & $*$ & VI" & VII" & VIII" & Total \\
\hline $\mathrm{N}_{1}-\mathrm{N}_{7}$ & V 18-21 & 2 & 11 & 36 & 10 & 8 & & & & 67 \\
\hline $\mathrm{N}_{8}-\mathrm{N}_{9}$ & VI 23 & 3 & 5 & 2 & & & & & & 10 \\
\hline $\mathrm{N}_{10}-\mathrm{N}_{12}$ & VII $24-27$ & 4 & 2 & 2 & & & 11 & 4 & 4 & 27 \\
\hline
\end{tabular}

* I: Pollen deposited (no eggs), II: Eggs, III: Small to medium larvae, IV: Large larvae, V: Post fedding larvae and prepupae, VI: White pupae, VII : Colored pupae, VIII : After emergence. 
$\left(\mathrm{N}_{1}\right), 11\left(\mathrm{~N}_{5}\right), 11.5\left(\mathrm{~N}_{4}\right), 12\left(\mathrm{~N}_{2}\right), 13\left(\mathrm{~N}_{6}\right.$, Cluster 2$)$, on the average $10.7 \mathrm{~cm}$ (SD, 1.56). On the other hand, in $\mathrm{N}_{8}-\mathrm{N}_{12}$ distribution of depths is 14 ( $\mathrm{N}$,, Cluster 1 , henceforth abbreviated $\mathrm{C}_{i}$. But depth of bifurcation issuing the lateroid is $18 \mathrm{~cm}$, which is used in calculating the mean, $26\left(\mathrm{~N}_{10}, \mathrm{C},\right), 27\left(\mathrm{~N}_{8}-\mathrm{C}_{2} ; \mathrm{N}_{10}-\mathrm{C}_{2}\right)$, $36\left(\mathrm{~N}_{10}-\mathrm{C}_{3}\right), 39\left(\mathrm{~N}_{9}\right), 41\left(\mathrm{~N}_{12}-\mathrm{C}_{1}\right), 43\left(\mathrm{~N}_{10}-\mathrm{C}_{4} ; \mathrm{N}_{11}-\mathrm{C}_{1}\right), 51.5\left(\mathrm{~N}_{11}-\mathrm{C}_{2}\right), 62.4\left(\mathrm{~N}_{12}-\right.$ $\left.\mathrm{C}_{2}\right)$, 75.7 $\left(\mathrm{N}_{11}-\mathrm{C}_{3}\right)$, 77. $3\left(\mathrm{~N}_{11}-\mathrm{C}_{4}\right)$, with the average depth $45.1 \mathrm{~cm}(\mathrm{SD}, 1.79)$, evidently much deeper than in $\mathrm{N},-\mathrm{N}$, . Moreover, in all $\mathrm{N}_{8}-\mathrm{N}_{12}$ remains of the spring cell clusters filled with soil are traced at shallower levels. These findings, together with the presence of more than one females in all $\mathrm{N}_{8}-\mathrm{N}_{12}$, are compatible with the life cycle characteristic to other social Evylaeus species, particularly L.duplex, which produce spring and summer broods discretely, and the corresponding cell clusters are made separately, much deeper in summer.

Pollen foraging in these nests was confirmed in May 18, June 23 and July 24. In L. duplex the duration of immature stages is approximately 38 days in spring

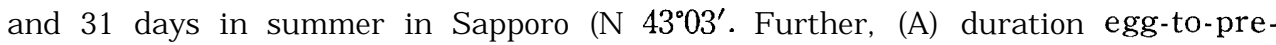
pupa $\div 15$ days in spring, (B) duration egg-to-black pupa $\div 29$ days in summer). These durations are unknown for the southerly distributed L.affine, but should not much deviate from those in $L$. duplex at the same latitudes, possibly a lit-

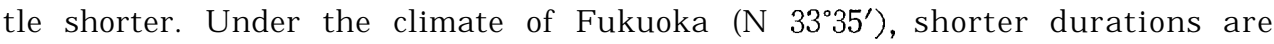
expected even though in part compensated by deeper locations of brood cells. Applying (A) and (B) to Table 1, the spring and summer foraging periods in Fukuoka are roughly estimated at late April-later May and late June-early August, respectively,

Fig. 1A summarizes the result of periodical sampling of adults on flowers surveyed in Morioka. Relative age of each female is expressed by degrees of mandibular and wing wear (Sakagami et al., 1974, Fig. 12). In this sample, extremely worn females (degrees 4,5) were not obtained. Disregarding a drop in mid August, which was probably weather affected, three active periods are recognized: $\mathrm{P}_{1}$ June-mid July, $\mathrm{P}_{2}$ August-September, $\mathrm{P}_{3}$ October. $\mathrm{P}_{1}$ obviously indicates brood rearing activity by post-hibernating females. Judging from the appearence of intact females, $\mathrm{P}_{2}$ and $\mathrm{P}_{3}$ respectively represent activities of newly emerged females. The whole picture closely resembles that in L. duplex (Sakagami and Hayashida, 1968, Fig. 1) and $\mathrm{P}_{1}-\mathrm{P}_{3}$ correspond respectively spring solitary phase, summer matrifilial (=eusocial) phase and autumn mating phase. That $\mathrm{P}_{1}$ corresponds to solitary phase in $L$. duplex is obvious, although nests in this phase of L.affine are sometimes polygynous as given later. From the results of nest excavation in Fukuoka alone, it is uncertain whether the summer active period represents a second generation or a matrifilial phase, that is, a eusocial association by the mother as principal egg layer (=queen) and her first daughters as foragers (=workers). Fig. 1 favors the latter interpretation by the smaller body size of females in $\mathrm{P}_{2}$ (Fig. 1B) and scarcity of males (Fig. 1 A. bottom) in the earlier half of $\mathrm{P}_{2}$. In L.duplex, about $4 \%$ of 


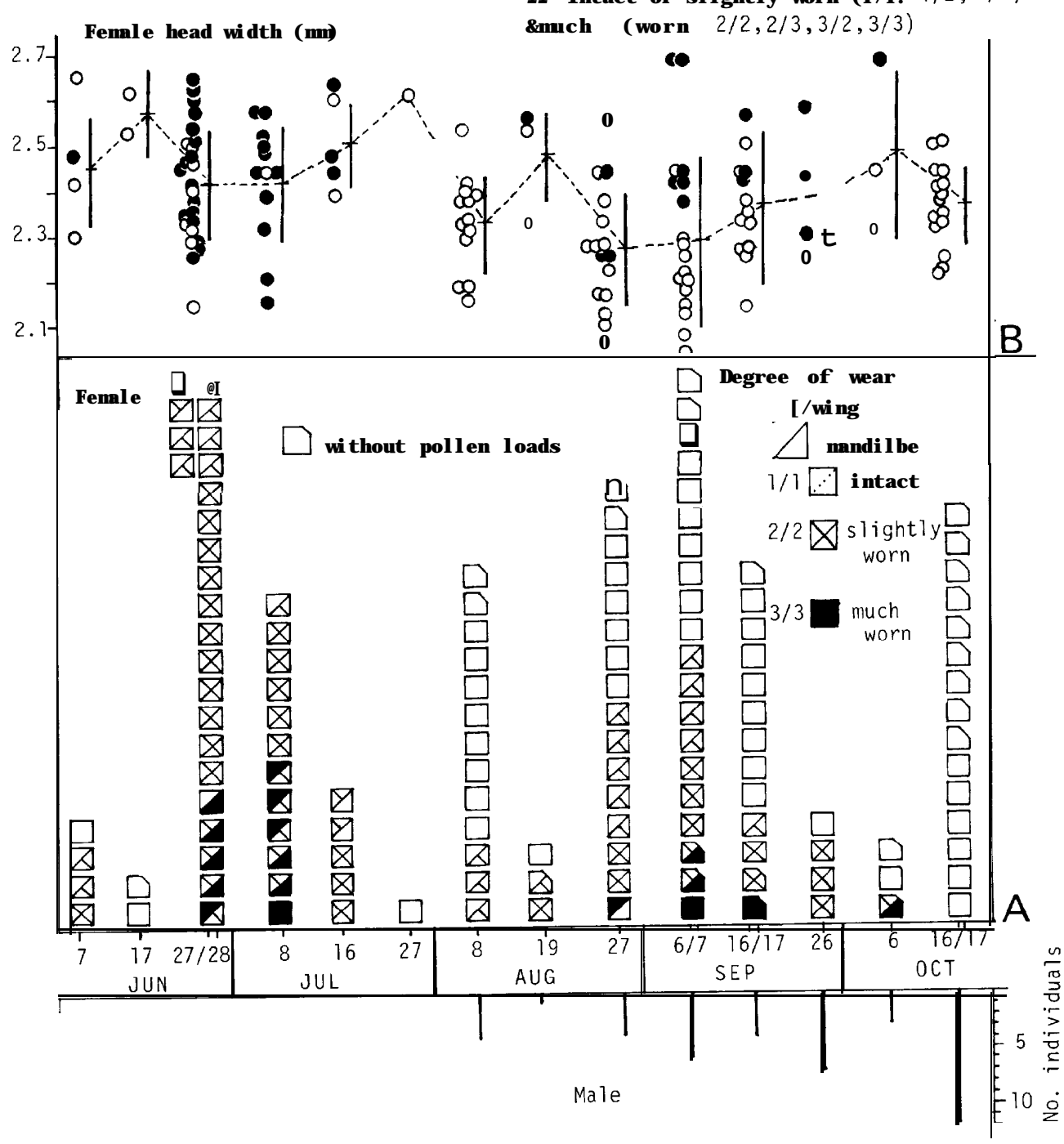

Fig. 1. Phenology of L. affine in Morioka based upon sampling on flowers every ten days. A. In females each square represents an individual, with indication of relatve age by wear of wings and mandibles. B. Size variation in females given by head width.

immatures reared in spring solitary phase are males. Some males of L.affine collected in the earlier half of August may correspond to those produced in $\mathrm{P}$,. Correspondence of $\mathrm{P}_{3}$ to the autumn mating phase of L. duplex is certain by the appearance of many males (Fig. 1 A) and increase of body size in females (Fig. 1B), prospective queens in the next year. Intact females collected in the later half of $\mathrm{P}_{2}$ might include such new queens, who have emerged slightly 


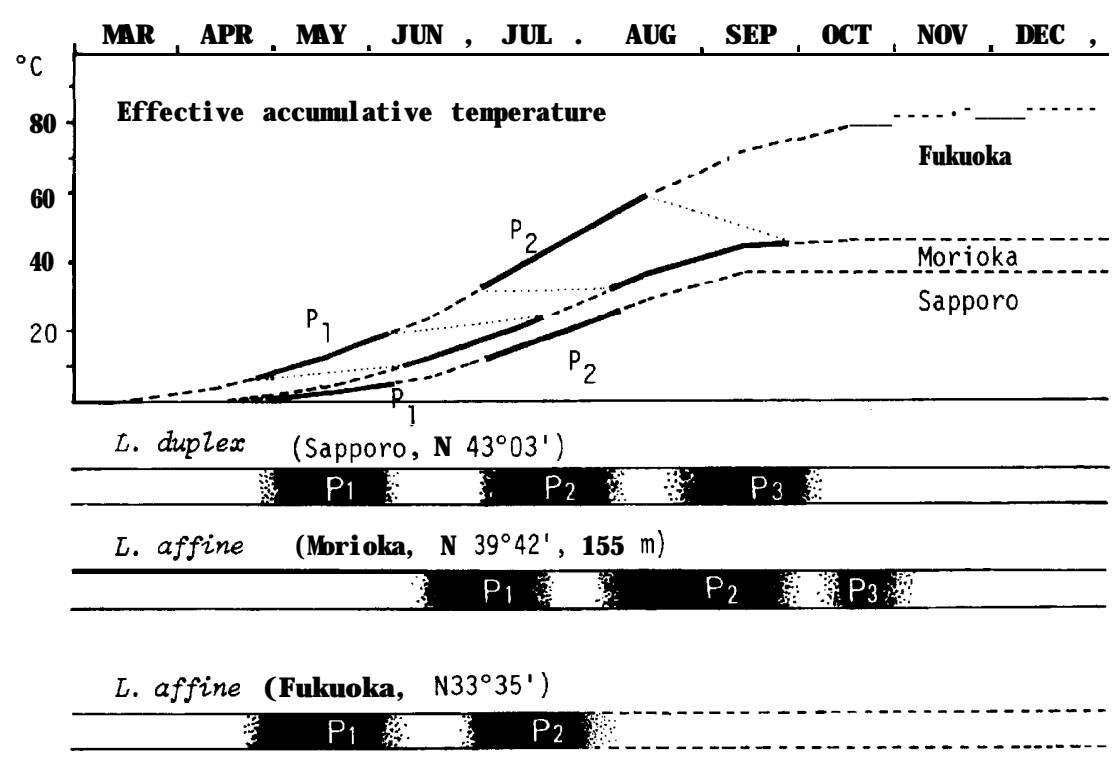

Fig. 2. Comparison of life cycle of L. affine in Fukuoka and Morioka, and of L. duplex in Sapporo. Three periods, $\mathrm{P}_{1}-\mathrm{P}_{3}$ explained in text.

later than males and, after mating, would enter in overwintering.

In conclusion, three active periods, $\mathrm{P}_{1}-\mathrm{P}_{3}$ well correspond to the life cycle of the related eusocial species $L$. duplex. Consequently, two estimated active periods in Fukuoka, late April-late May and late June-late July in L.affine should represent the solitary (or polygynous) and matrifilial phase of this eusocial species, respectively.

Fig. 2 gives the life cycle in Fukuoka and Morioka synoptically with the life cycle of L. duplex in Sapporo. As an index of local thermal condition, effective accumulative temperature was adopted, conveniently calculated from $T=\sum t_{i}\left(t_{i}\right.$ is mean air temperature in month $i$, when $\left.t_{i}>10\right)$. Subtraction of $10^{\circ} \mathrm{C}$ was made based upon the concentration of the developmental zero of many insects around this level (Utida, 1957).

Fig. 2 shows both $\mathrm{P}_{1}$ and $\mathrm{P}_{2}$ in Fukuoka start about 1.5 months earlier than in Morioka, coinciding with those of L. duplex in Sapporo. A rough correspondence of start and end of $\mathrm{P}_{1}$ and $\mathrm{P}_{2}$ exists between Fukuoka and Morioka with respect to $T$. On the other hand, the life cycle of $L$.duplex is evidently more cool adapted, although the summer broods of both species seem to be reared under similar thermal condition (cf. Nest development). However, the life cycle schema of Fukuoka is tentative, as both $P_{1}$ and $P_{2}$ might actually be longer (cf. Nest development and colony population).

In Fukuoka no records were taken after July. The sequence is probably continuation of $\mathrm{P}_{2}$ for a while, followed by appearance of $\mathrm{P}_{3}$ producing reproductives (sex ratio $\div 1.0$ and females larger than in $\mathrm{P}_{2}$ ). But insertion of a 
second $\mathrm{P}_{2}$ before $\mathrm{P}_{3}$, i.e. repetition of worker brood production, cannot absolutely be precluded. Most social species of Evylaeus produce only worker brood, but L. (E.) malachurum (Kirby) produces it twice in central Europe (cf. Sakagami, 1974) and possibly thrice in Italy (Bonelli, 1942). Such possibility in L.affine in S. Japan, where thermal and floral conditions are still favorable in early to mid autumn, should be tested through further researches.

Inversely, the life cycle in northern areas is also of bionomic interest. In $L$. calceatum inhabiting Hokkaido, a lowland population exhibits a life cycle similar to that in L.duplex and L.affine. On the other hand, a solitary life cycle was confirmed on the top of Mt. Yokotsu $(1,167 \mathrm{~m})$ (Sakagami and Munakata, 1972). L.affine reaches northward in the Continent Charbin, N. China (Ebmer, 1978 a) and in Japan the southernmost area of Hokkaido. Two females both collected at Yunokawa, Hakodate City in 1961 by Prof. M. Munakata were examined by S. F. S., both with pollen loads and intact wings. One female collected on July 2 had intact mandibles with head and metasomal widths 2.68 and $3.06 \mathrm{~mm}$ respectively. Another collected on August 18 had slightly worn mandibles, and head and metasoma 2.59 and $2.75 \mathrm{~mm}$ wide. It is still difficult to guess the life cycle there from these meager materials.

\section{Caste differences}

Fig. 1B shows the appearance of small sized females in August and September, which were considered above the workers. However, size variation is conspicuous throughout the sampling period. In L. duplex, a few spring females repeat brood rearing solitarily in summer. Further, some large and heavily worn females, certainly the senile spring females, are collected in late summer to autumn. In L.affine, too, it is possible that some large and worn females collected in summer (Fig. 1B) represent such old spring females. These should be excluded for demonstration of caste-linked size difference. Here the females collected from June 7 to July 16 and on October 16 and 17 were regarded as queens and not much worn females (degrees 1/1, 1/2 and 2/1) collected in August and September as workers. Fig. 3 presents size relation between these castes, shown with head and metasomal widths. Although queens are on the average larger than workers, overlap is considerable. The mean head widths of these two castes are:

$\begin{array}{llccl}\text { Caste } & \overline{\mathrm{x}} & \mathrm{SD} & \mathrm{n} & \mathrm{c} \mathrm{v} \\ \text { Queen } & 2.42 \mathrm{~mm} & 0.12 & 64 & 5.10 \% \\ \text { Worker } & 2.28 & 0.12 & 56 & 5.48 \\ \text { All females } & 2.37 & 0.12 & 135 & 5.19\end{array}$

The difference between queens and workers is statistically significant $(t=$ 48.5, $p<0.001$ ). The mean difference, $5.8 \%$ is less than in L. duplex (6.7, Sakagami and Hayashida, 1968), slightly more than in L.calceatum in Hokkaido (5.5 


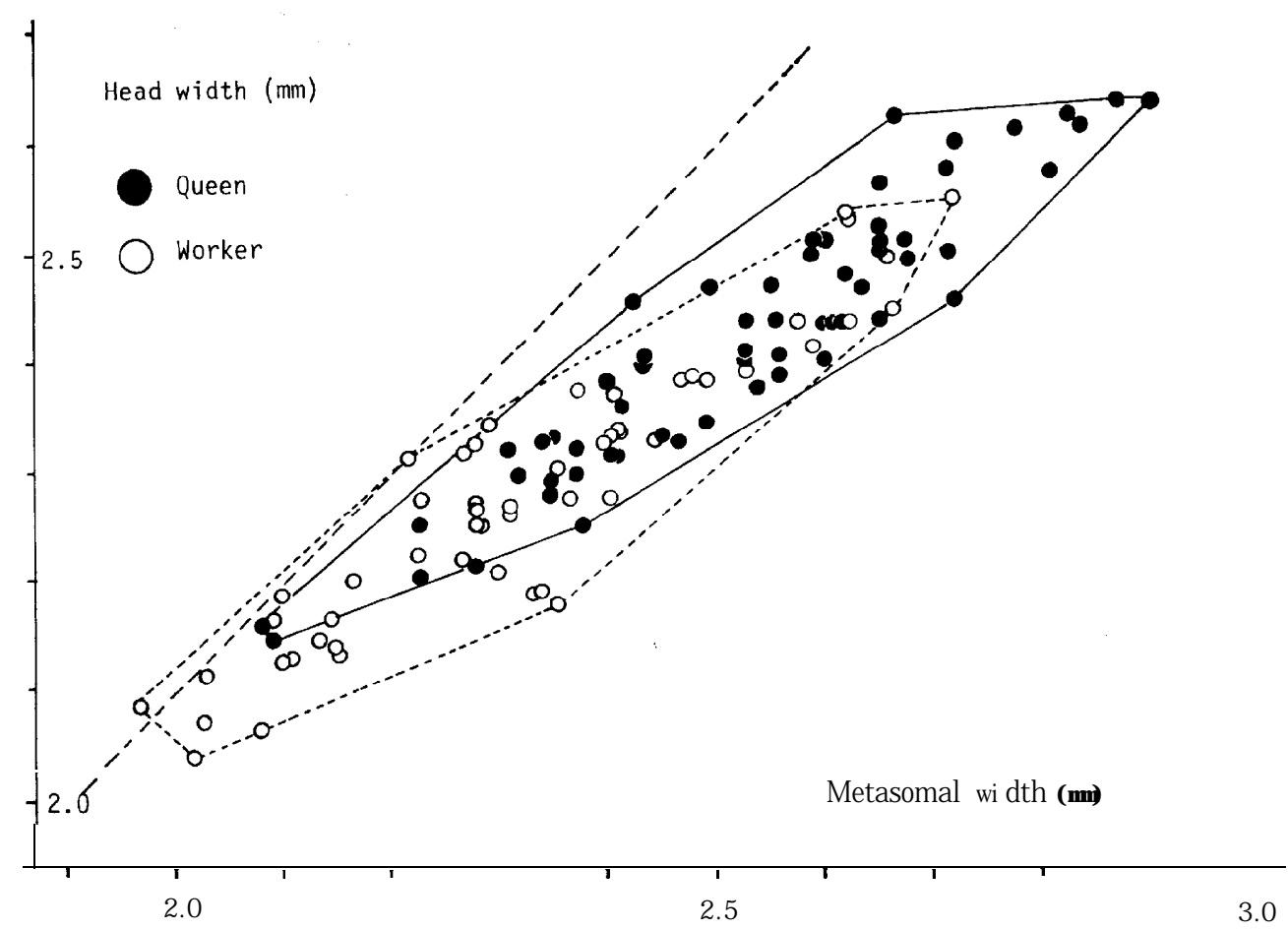

Fig. 3. Size variation in queens and workers of L. affine in Morioka.

$\%$, Sakagami and Munakata, 1972), but much less than in L.calceatum in France (13\%, Knerer and Plateaux-Quénu, 1967 b). It is noteworthy that coefficient of variation does not much differ between each caste and total females. This implies a large size variation not only as a whole but also within each caste. Lin and Michener (1972) regarded increased size variation in some eusocial halictine bees as an outcome of a production of young throughout the season under variable conditions than of sociality. This assumption should be tested through further analyses.

Except for size, there are no morphological caste differences. Fig. 3 shows a slight allomorphic tendency, the metasoma being much wider in larger females as in L.duplex (Sakagami and Hayashida, 1968) and L.calceatum (Sakagami and Munakata, 1972). The ratio genal width/eye width was not measured, but there is no obvious allomorphosis as seen in some halictine groups (Sakagami and Moure, 1965; Sakagami and Wain, 1966).

\section{Nest architecture}

The nest aggregation studied in Fukuoka was located in a red clay hill sparsely covered with young pines. Most nests were found on patches of bare horizontal or slightly sloping ground, where root systems were sparse but the 


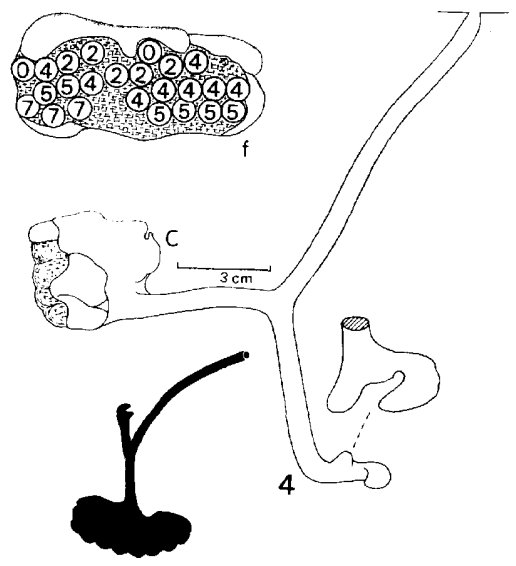

Fig. 4. Polygynous early spring nest $(\mathrm{N}$,$) . Symbols used in this and sub-$ sequent figures: Lined and shillouete figures of nest burrows (lateral and top views) ; C' (old comb cavity filled with soil); $\mathrm{C}_{i}$ (comb cavity numbered in the order of construction) ; f, r, d (frontal, rear and top views of comb cavities), numerals given in cells (developmental stages, $\mathrm{O}=$ new cell before pollen deposition, $1=$ with pollen but not yet egg, $2=$ egg, $3-5=$ small, medium and large larvae, $6=$ prepupa, $7=$ pupa, $8=$ adult), $\mathrm{X}$ (loosely filled with soil).
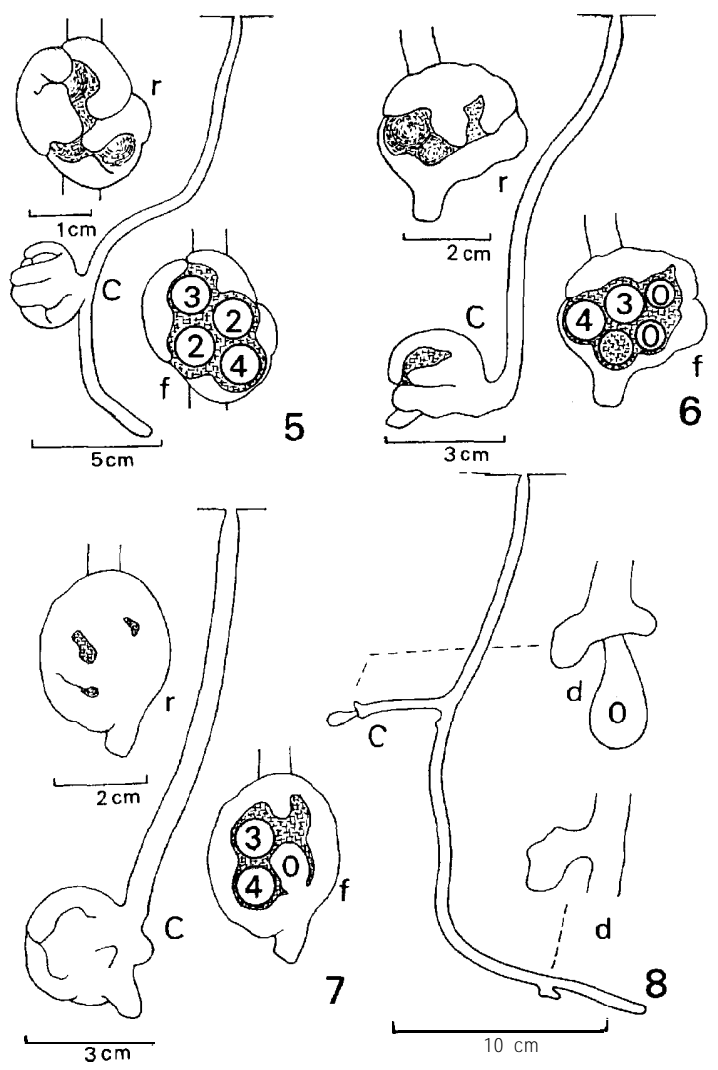

Figs. 5-8. Solitary early spring nests $\left(\mathrm{N}_{2}-\mathrm{N}_{5}\right)$.

soil was very hard and contained some pebbles.

The nests were found irregular in distribution ; some were' $1 \mathrm{~m}$ apart but some were only $10 \mathrm{~cm}$. About 100 nests were observed in $20 \mathrm{~m}^{2}$.

Figs. 4-15 shows the nests studied in Fukuoka. The nest pattern is type V (Sakagami and Michener, 1962; Va' in Sakagami, 1974), characterized by formation of one or more horizontal unilateral combs each surrounded with a cavity, the comb-cavity system communicating with the mean burrow usually by means of a short horizontal burrow or lateroid.

Tumulus, if present, radial and central (Fig. 12, N,) ; inner wall often smooth but not consolidated with saliva. Entrance constricted, 3-4 mm wide, without turret. No special enlargement immediately below entrance. Depth to bottom of blind burrow 15 to $40 \mathrm{~cm}$ in spring, 40 to more than $80 \mathrm{~cm}$ in summer, burrow 5.5-6.5 mm wide, without special enlargement; inner wall fairly smooth, without special lining; general direction vertical, often slanting or irregularly bending (Figs. 13, 14), in summer often issuing short 

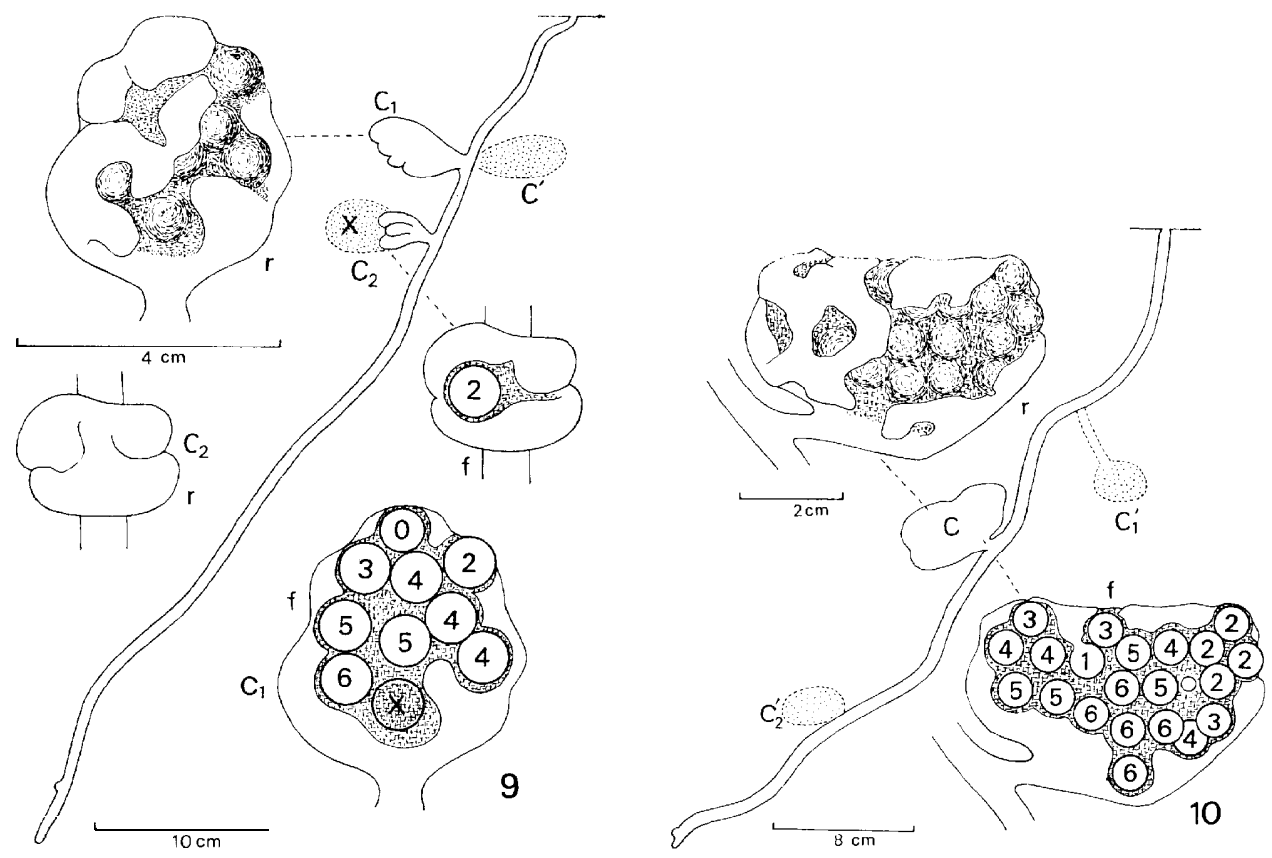

Figs. 9 and 10. Polygynous late spring nests $\left(N_{,}, N_{7}\right)$.

branch burrows, rarely ramified (Fig. 13). Lower blind burrow present but very short in some incipient spring nests (Figs. 6, 7). Lateroid vestigial to distinct; if long, attaining $4 \mathrm{~cm}$, horizontal or ascending, as wide as main burrow, usually straight and opening to the lower half of comb cavity; inner wall as in main burrow; depth to entrance of lateroid $8-13 \mathrm{~cm}$ in spring nests, $27-77 \mathrm{~cm}$ in summer ones.

Cells horizontal, forming a comb, slightly divergent at back. Surface of cell cluster smooth, being so elaborated that shape of each cell is externally detectable. After completion, cell cluster supported within cavity only by several pillars. Interspace between cluster and cavity wall narrow but sometimes as wide as cell. Number of cluster per nest one, exceptionally two (Fig. 9) in spring, one to four in summer. Younger ones usually made deeper (Figs. 9, 11, 14, 15).

Cells elongated oval and bilaterally symmetrical, with underside flater, 13$14 \mathrm{~mm}$ long, 6.5-7 mm wide, 3-4.5 $\mathrm{mm}$ in neck diameter; inner wall smooth and polished except for neck. Pollen ball subspherical, distinctly flattened, dough-like. Cell closure loose and permeable. Developmental gradient progressive and ascending in cluster.

Summarizing the nest architecture is very similar to that of L.duplex. Some comments are given as to the presence of lateroid. Nearly all combmaking Evylaeus species excavate cells directly on the inner wall of the main 

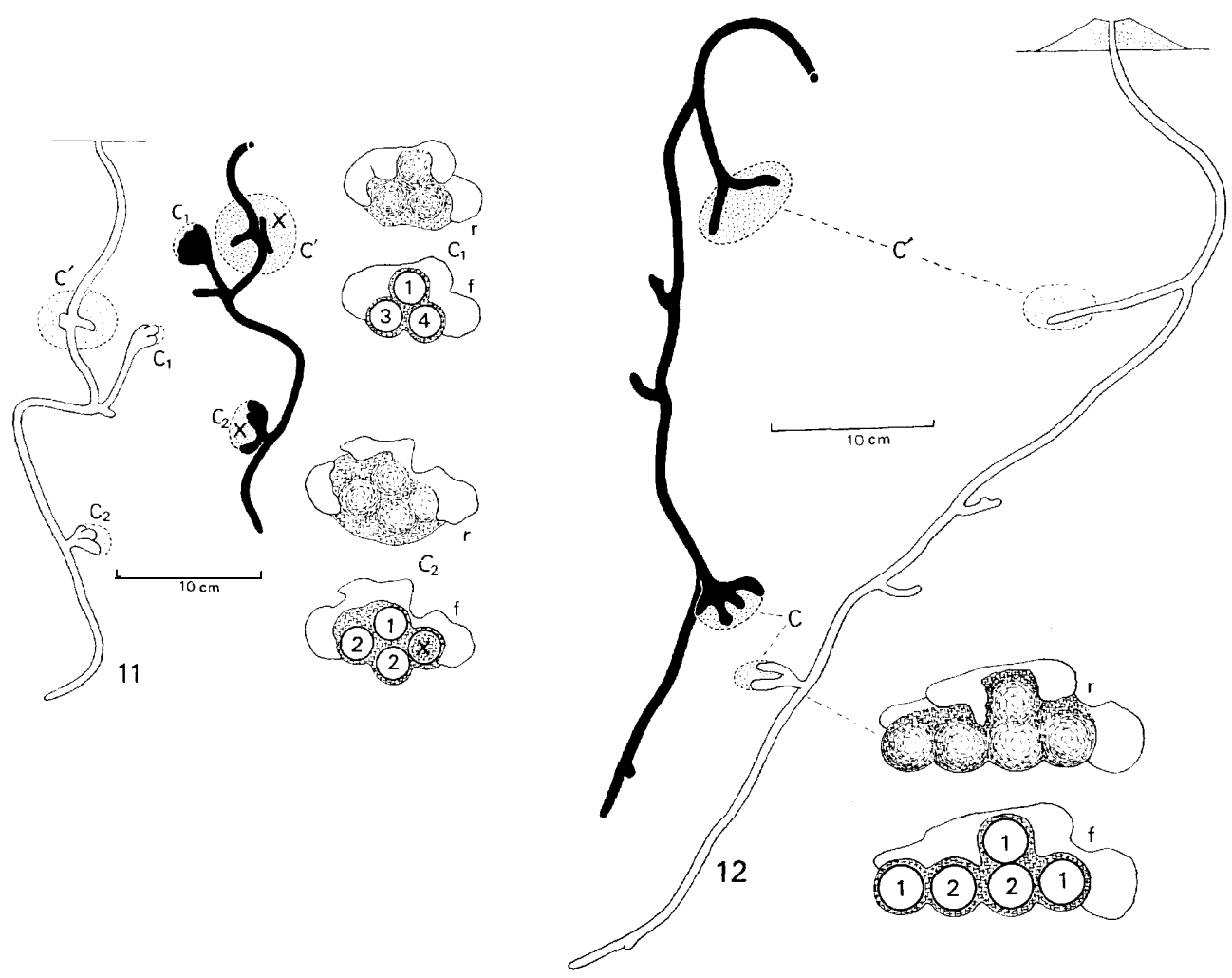

Figs. 11 and 12. Early summer matrifilial nests $\left(\mathrm{N}_{8}, \mathrm{~N}_{9}\right)$.

burrow (Sakagami, 1974), without preparing lateroid, named by Sakagami and Michener (1962) to distinguish it from genuine laterals in other halictine bees (e. g. Lasioglossum s. str.), which are narrower than the main burrow and filled,with soil after the closure of cells. Until the present, lateroid formation in Evylaeus is known only in L.duplex and a Japanese population of L.calceatum but not always of the European populations of the same species (Sakagami and Munakata, 1972). L.affine is a third Evylaeus species possessing this architectural peculiarity. However, lateroid in this species seems to be more facultative than in L.duplex. Among the nests examined, lateroid was $2-4 \mathrm{~cm}$ long in $\mathrm{N}_{1}, \mathrm{~N}_{5}, \mathrm{~N}_{8}\left(\mathrm{C}_{1}\right)$ and $\mathrm{N}_{11}\left(\mathrm{C}_{3}\right)$ (Figs. $4,8,11,14$ ), virtually absent in $\mathrm{N}_{4}$ (Fig, 7) and $\mathrm{N}_{10}\left(\mathrm{C}_{\text {, }}\right.$ Fig. 13), and very short to sessile in all other combs. In $\mathrm{N}_{2}, \mathrm{~N}_{4}$, $\mathrm{N}_{8}\left(C_{1}\right), \mathrm{N}_{10}\left(\mathrm{C}_{3}\right)$, lateroid is communicated with the middle of the cavity, while all other combs, excluding newly started ones $\left(\mathrm{N}_{2}, \mathrm{~N}_{3}, \mathrm{~N}_{6}-\mathrm{C}_{2}, \mathrm{~N}_{7}, \mathrm{~N}_{8}\right.$ $\mathrm{C}_{1}, \mathrm{~N}_{9}, \mathrm{~N}_{10}-\mathrm{C}_{4}, \mathrm{~N}_{11}-\mathrm{C}_{1}, \mathrm{C}_{3}, \mathrm{C}$, ), with the bottom. On this aspect, L. affine resembles $L$. duplex, and differs from $L$.calceatum in Hokkaido, in which communication of lateroid with the upper part of the cavity prevailed. Correspondingly, the upward developmental gradient was predominant $\left(\mathrm{N}_{1}, \mathrm{~N}_{6}, \mathrm{~N}_{7}, \mathrm{~N}_{8}\right.$ - 


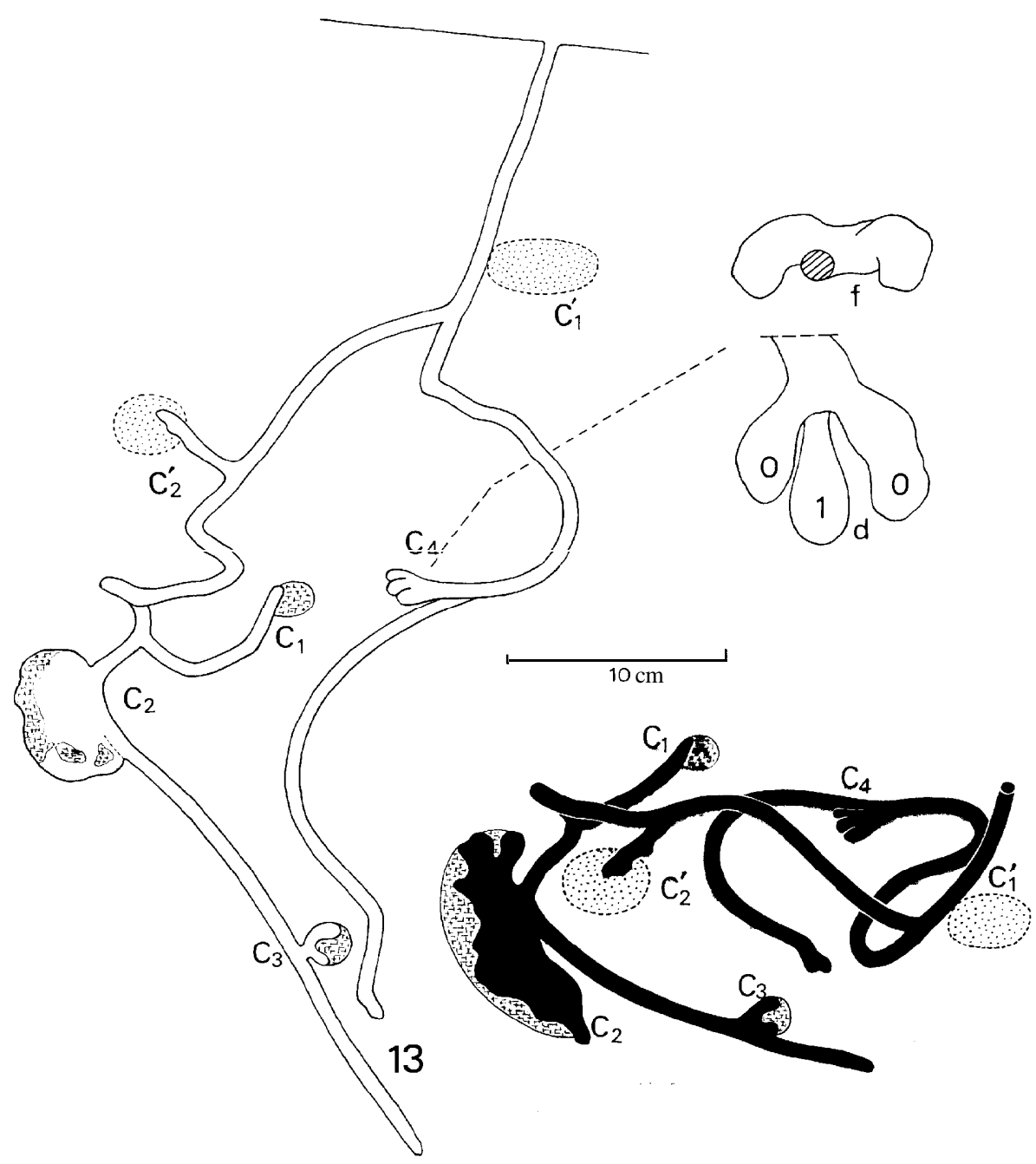

Fig. 13. Late summer matrifilial nest $\left(\mathrm{N}\right.$, ,). Nest contents : $\mathrm{C}_{1}\left(2\right.$ white pupae), $\mathrm{C}_{2}$ (2 halfpigmented pupae, 3 older pupae, 5 adult females), $\mathrm{C}_{3}(2$ white pupae), 8 adult females in main burrow.

$\mathrm{C}_{1}, \mathrm{~N}_{9}, \mathrm{~N}_{11}-\mathrm{C}_{4}$, and even in $\mathrm{N}-\mathrm{C}$, , which received lateroid at the middle). The downward gradient was seen only in $\mathrm{N}_{2}$. The variable nature of lateroidcomb/cavity relation might indicate an instability of nest structure as in $L$. calceatum (Sakagami and Munakata, 1972).

Nest development and colony population

In contrast to $L$. duplex, reuse of old nests and formation of polygynous association in spring appear to be frequent in L.affine. Three out of seven spring nests $\left(\mathrm{N},, \mathrm{N}_{6}, \mathrm{~N}_{7}\right.$, Figs. 4, 9, 10) were polygynous, containing 5, 4, 3 


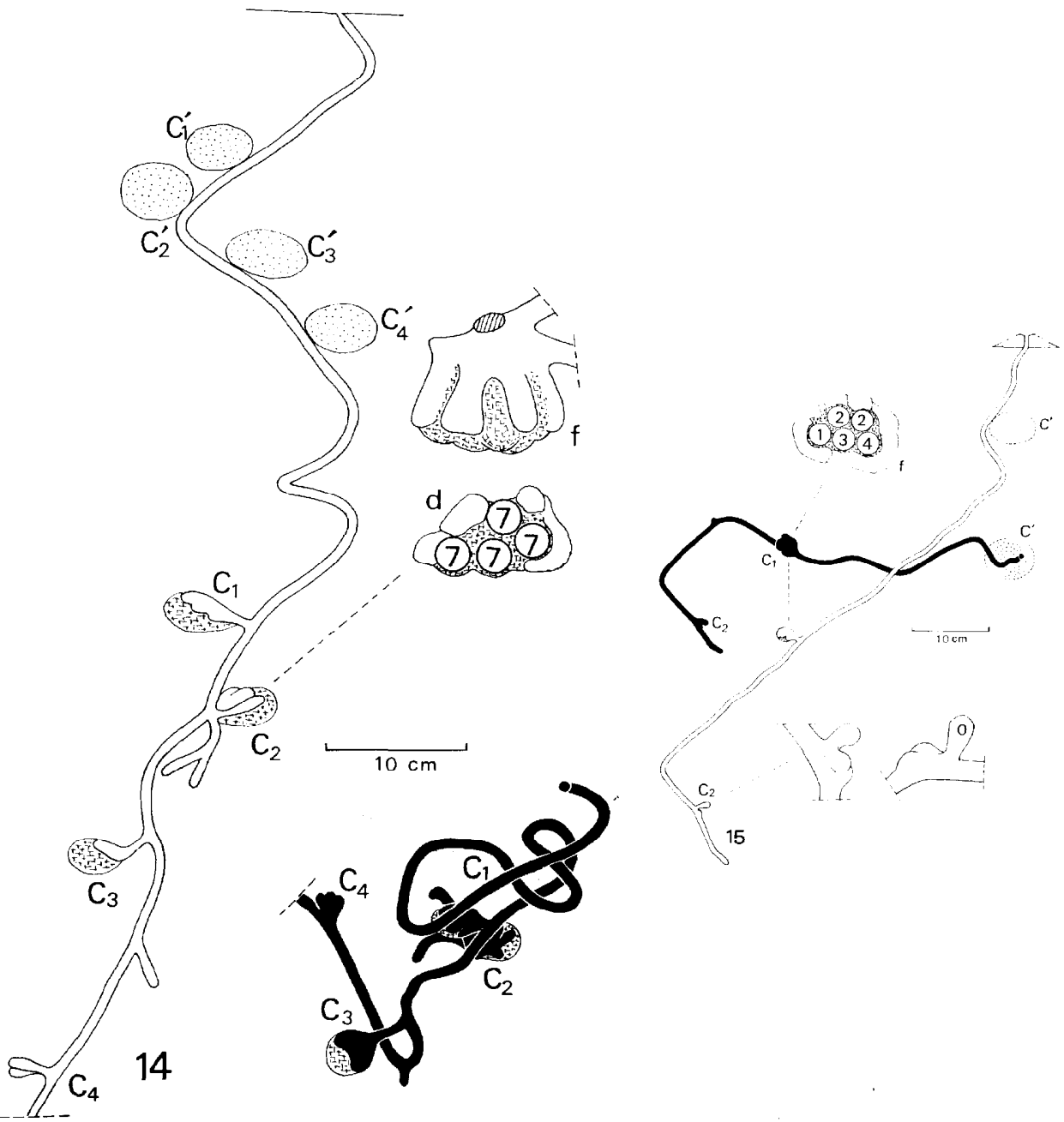

Figs. 14 and 15. Late summer matrifilial nests $\left(\mathrm{N}_{11}-\mathrm{N}_{12}\right)$. Nest contents in $\mathrm{N}_{,,}: \mathrm{C}_{1}$ ( 1 adult female, 4 or more post emergence), $\mathrm{C}_{2}$ (2 males emerged on July 29), $\mathrm{C}_{3}$ (3 white pupae $), C_{4}(3$ cells with pollen $)$.

females, respectively. $N_{6}$ and $N_{7}$ had each one old spring cavity filled with soil ( $C^{\prime}$ in figures). In $\mathrm{N}_{1}$ the old cavity was not confirmed but. interestingly, the females prepared the comb-cavity, extending the old cavity, probably made in the prior spring, judging from the depth. Presence or absence of nest reuse is difficult to ascertain for summer nests, because C' remains even in nests newly founded in spring. However, $N_{10}$ and $N_{11}$ are considered reused nests by the presence of many C', $\mathrm{N}_{2}, \mathrm{~N}_{3}$ and $\mathrm{N}_{4}$ are evidently newly started spring nests, the blind burrows of which are still short. In $N_{3}$ the blind burrow issues from the bottom of the cavity. Such anomaly is occassionally 
found in L.duplex, too (Sakagami and Hayashida, 1960). $\mathrm{N}_{5}$ contained only one cell just prepared, but its long blind burrow might indicate reuse of an old nest, the old cavity of which was overlooked.

In both spring and summer nests, the first cell of each comb is excavated in soil. At this stage, the cells are not yet surrounded by the cavity $\left(\mathrm{N}_{5}\right.$, $\mathrm{N}_{12}$ ). But the cells are soon surrounded with a cavity. In a previous paper on L. duplex (Sakagami and Hayashida, 1969), S. F. S. assumed construction of cells by excavation alone, not using building technique. Subsequent observations of many nests with a small comb but completely surrounded with a cavity have disfavored this interpretation. From observations of cell construction through glass walls, Plateaux-Quénu (1973) confirmed adoption of both excavating and building techniques by L.calceatum. The same procedure may be taken by both L. duplex and L.affine for expansion of combs.

In L. duplex studied in Sapporo depth of the bottoms of spring and summer cavities ranged 5-17 $\mathrm{cm}$ (mostly 7-11 cm) and 5-39 cm (mostly 11-21 cm), respectively, and the deepest lower blind burrow attained 25 to $30 \mathrm{~cm}$ (Sakagami and Hayas hida, 1960). Apparently reflecting the warmer climate in Fukuoka, the comb-cavity of L.affine were located much deeper as mentioned previously (cf. Life cycle). Correspondingly, the lower blind burrow of summer nests reached down to 38 and $57 \mathrm{~cm}$ in June and 52, 73 and more than $80 \mathrm{~cm}$ in July. On July 27, 1959, habitat temperature ("C) was measured at $17: 00$ as follows: air (30), soil $5 \mathrm{~cm}$ deep (38), $10 \mathrm{~cm}(35.5), 20 \mathrm{~cm}(31.0), 30 \mathrm{~cm}(29.5), 50 \mathrm{~cm}$ (25.5). The cavities excavated on the same day located between $40-77 \mathrm{~cm}$, hence were supposed to have been exposed to the range of soil temperatures about $20-27^{\circ} \mathrm{C}$. For L. duplex in Sapporo, soil temperatures at depths of summer cavities ranged approximately $18-25^{\circ} \mathrm{C}$, and was $21-22^{\circ} \mathrm{C}$ at the depths most preferred (Sakagami and Hayashida, 1960, Fig. 99), being roughly comparable to the summer brood cells of L.affine as for thermal condition.

Another interesting trait in L.affine is the frequent preparation of more than one comb. Even a spring nest $\mathrm{N}_{6}$ prepared two combs (no. of cell, in each comb, in the order of construction 10,1), and four out of five summer nests made, two or more combs $\mathrm{N}_{8}(3,4), \mathrm{N}_{10}(2,10,2,1), \mathrm{N}_{11}$ (more than 4, 2, 3, 3), $\mathrm{N}_{12}$ $(5,1)$. In L. duplex in Sapporo, no more than two combs were prepared in summer, and the ratio of these nests to total examined nests $(n=161)$ was only 11-14 \% (Sakagami and Hayashida, 1960, Table 15). This difference might reflect the difference in the number of adult females per summer nest. In $L$. duplex, the number of daughter females in summer nests was 3.7 on the average $(n=40, S D=1.97)$ and the maximum number, 8 , was represented by only one nest (Sakagami and Hayashida, 1968). In L.affine the number ( $n$-l, subtracting the mother) was distributed $3(\mathrm{~N},),, 5\left(\mathrm{~N}_{8}\right), 6\left(\mathrm{~N}_{11}\right), 7\left(\mathrm{~N}_{10}\right), 11\left(\mathrm{~N}_{9}\right)$, much higher than in L. duplex although the sample size is small. The presence of many females may increase the chance of starting new combs. In $L$. 
duplex, formation of many combs was experimentally induced by increasing the number of female pupae during the inactive phase preceding the matrifilial phase (Sakagami and Hayashida, 1968).

The number of cells produced in each nest was distributed:

Spring monogynous nests : $1\left(\mathrm{~N}_{5}\right), 3\left(\mathrm{~N}_{4}\right), 4\left(\mathrm{~N}_{2}\right), 5\left(\mathrm{~N}_{3}\right)$

Spring polygynous nests : $11\left(\mathrm{~N}_{6}, 2.8\right.$ per female), $21\left(\mathrm{~N}_{7}, 7\right.$ per female),

$24(\mathrm{~N}, 4.8$ per female $)$

Summer nests : $5(\mathrm{~N}),, 6(\mathrm{~N}),, 7\left(\mathrm{~N}_{8}\right), 14\left(\mathrm{~N}_{10}\right),>13\left(\mathrm{~N}_{11}\right)$

The number of cells are not much higher than in L. duplex, in which spring and summer nests produce $5-7$ and $3-41(\bar{x}=14.4)$ cells, respectively. This may be caused by the fact that many examined nests had still continued brood rearing activity. Consequently, both $\mathrm{P}_{1}$ and $\mathrm{P}_{2}$ might be longer than given in Fig. 2.

In multifemale nests of this species, the nest entrance is guarded in the daytime as in most social halictines. Guards do not allow entry of females who probably are not the nest mates. Frequent stimulation releases either withdrawal or turning followed by metasomal guarding, which is fairly persistent. Artificial removal of a guard was often replaced by another female. In one nest, the replacement was repeated up to four times in about one hour.

\section{Flower visits}

In periodical sampling made in 1976 in Morioka, the flowers visited by bees were recorded for each specimen. The plants visited by L.affine are listed below in the descending order of the number of specimens captured on them. In parentheses are givena bbreviations for species names, families, provenance of the plants ( $\mathrm{E}=$ exotic weed, $\mathrm{N}=$ native, $\mathrm{W}=$ native weed. Distinction between $\mathrm{N}$ and $\mathrm{W}$ is sometimes tentative) and the number of specimens expressed as ? p (females carrying pollen loads) + 우 $\mathrm{n}$ (females without pollen loads) + $\sigma^{\pi}=$ total.

Erigeron annuus (Ea, Compositae, E, 43 ㅇp $+1+\mathrm{n}=44)$, Picris hieracioides (Ph, Comp., $\mathrm{W}, 19$ ㅇ $\mathrm{p}+9$ 우 $\mathrm{n}+12 \precsim=40)$, Lactua indica (Li, Comp., N, 11우 $\mathrm{p}+7 \sigma^{-18}$ ), Rudbeckia laciniata ( $R l$, Comp., E, 6 우 $\mathrm{p}+4$ 우 $\mathrm{n}+3 \hat{\sigma}=13$ ), Ixeris dentata (Id, Comp., N, 7 우 $)$, Youngia denticulata (Yd, Comp., NW, 6 우 p), Helianthus tuberosus (Ht, Comp., E, 3 우 p-i$1 q \mathrm{n}+1 \sigma^{-5}$ ), Circium sp. 1 (C, Comp., 4qp), Aster glehni var. hondoensis (Ag, Comp., $\mathrm{N}, 3$ \% $+1 ठ=4)$, Senecio cannabifolius ( $\mathrm{SC}$, Comp., N, 2 ㅇ $\mathrm{p}+2$ i $\mathrm{n}=4)$, Patrinia villosa $\left(P v\right.$, Valerianaceae, N, 2 ㅇ $\mathrm{p}+1 \delta^{\Uparrow=3}$ ), Oenothera lamarkiana (Ol, Onagraceae, E, 2 우 p), Ixeris dentata var. albiflora f. amplifolia (la, Comp., N, 2 o f p), Trifolium repens (Tr, Leguminosae, E, 1 요 n), Cirsium sp. 2 ( $C_{2}$, Comp., 1 우 p), C. nipponicum (Cn,Comp., $\mathrm{N}, 1$ ㅇp p), Esholtizia ciliata (EC, Labiatae, NW, 1 요 n), Aster inumae (Ai, Comp., N, 1우 p), Taraxacum officinale (Ta, Comp., E, 1 우 n), Vicia unijuga (Vu, Legm., N, 1ठ), Eupatorium chinense var. simplicifolium (Ep, Comp., N, 1ð). 
At family level, Compositae are overwhelmingly visited, occupying 16 out of 21 visited species, obviously in part dependent on their abundance. From the top to tenth visited species belong to this family and visits to five top species occupy $76.5 \%(121 / 158)$ of total visits. As to the provenance of plants species, ten species are natives, six are exotic weeds, three are native weeds and two Cirsium unidentified. However, in terms of percentage visits, exotics (66 visits) and native weeds (46 visits) in combination occupy $\mathbf{7 0 . 8} \%$ of total visits. The survey was mainly made along the roads penetrating forests. The above result indicates invasion of exotic and native weeds into forest margins, a situation now widespread in Japan. Anyhow, dependence on these secondary weeds indicates the polytrophic and -lectic nature of L.affine as in many halictine species. However, few visits to two most predominant weeds in northern Japan, Taraxacum officinale and Trifoliumrepens, are recognized. The former case simply reflects the relatively late start of foraging activity of $L$. affine. As to disregard for T. repens, which was abundant in the area during the foraging period, L.affine resembles L.calceatum (Sakagami and Munakata, 1972) and L.duplex (Sakagami, unpub.), contrasting to the partiality to the legumes by some halictine species of Halictus s. str., Seladonia, and Lasioglossum s. str. (Sakagami and Fukuda, 1973).

The phenology of visits to particular plant species are given below, each month separately (number of visits in parentheses ; if not, a single visit) :

Females, June $E a(23), I d(6), C_{\text {, }} T r$; July $E a(13), C_{1}, O l$ (2); Id, August $E a(8), P h$

(5), $H t, P l(4), S c(3), P v, I a, A g(2), C_{2}, C n$; September $L i$ (15), Ph (12), Yd (4), $P l(2), E a, A g$; October $P h(12), R l(2), Y d, E C, A i, T o$. Males, August $P h, R l(2)$, $H t, P v, A g, V u$; September $L i(7), P h(4), R l(3), Y \mathbf{d}, E p$; October $P h$ (12), $R l$ (3) .

Important food sources for the local population were Erigeron annum in the solitary phase $\left(\mathrm{P}_{1}\right)$ and Picris hieracioides, Lactua indica and Erigeron annum in the eusocial and mating phases $\left(\mathrm{P}_{2}, \mathrm{P}_{3}\right)$.

\section{Acknowledgements}

We express our thanks to Prof. Meiyo Munataka, Hokkaido Gakugei University, Hakodate branch, Hakodate, for his kindness in offering us chorological information, and to Mrs. Ikuko Numasa, Institute of Low Temperature Science, Hokkaido University, Sapporo, for her help in preparing this paper.

\section{References}

Bonelli, B. 1948. Osservazioni biologiche sull' Halictus malachurus Kirby (HymenopteraApidae). Boll. Ist. Ent., Univ. Bologna 17:22-42.

Ebmer, A. W. 1978 a. Die Halictidae der Mandschurei (Apoidea, Hymenoptera). Bonn. Zool. Beitr. $29: 183-221$.

— 1978 b. Die Bienen der Gattungen Halictus Latr., Lasioglossum Curt. und Dufourea Lep. (Hymenoptera, Halictidae) aus Korea. Ann. Hist. nat. Mus. Nat. Hung., 70: 307-319. 
Hirashima, Y. 1957. A tentative catalogue of the genus Halictus Latreille of Japan, and her adjacent territories (Hymenoptera, Halictidae) . Sci. Bull. Fac. Agr., Kyushu Univ. 16: $1-30$.

--- 1960. An interesting habit of the full-grown larvae of Haluctus affinis Smith, apparently correlated with the function of the Malpighian tubes (Hymenoptera, Halictidae) . Mushi 33 (11) : 85-88

Knerer, G. and C. Plateaux-Quénu 1967a. Sur la production continue oupériodique de couvain chez les Halictinae (Insectes, Hyménoptères). CR. Acad. Sci. Paris D. 264: 651-653.

Lin, N. and C. D. Michener 1972. Evolution of sociality in insects. Quart. Rev. Biol. 47 : 131-159.

Michener, C. D. 1974. The social behavior of bees, a comparative study. Harvard Univ. Press, Cambridge, Mass., xi+404 pp.

Plateaux-Quénu, C. 1973. Construction et evolution annuelle du nid d'Evylaeus calceatus Scopoli (Hym. Halictidae) avec quelques considerations sur la division du travail dans les sociétés monogynes et digynes. Ins. Sociaux 20: 297-320.

Sakagami, Sh. F. 1974. Sozialstruktur und Polymorphismus bei Furchen- und Schmalbienen (Halictinae). In G. H. Schmidt ed., Sozialpolymorphismus bei Insekten. Probleme der Kastenbildung im Tierreich, xxiv +974 pp., Wiss. Verlagsgesellschaft, Stuttgart, pp. 257-293.

1977. Seasonal change of nest survival and related aspects in an aggregation of Lasioglossum duplex (Dalla Torre), a eusocial halictine bee (Hymenoptera : Halictidae) . Res. Popul. Ecol., 19: 69-86.

- - Fukuda, H. and H. Kawano 1974. Biofaunistic surveys of wild bees. Problems and methods, with results taken at Mt. Moiwa, Sapporo. Materials Biol.Educ.9: l-60. (In Japanese with English summary)

__ and H. Fukuda 1973. Wild bee survey at the campus of Hokkaido University. J.Fac. Sci., Hokkaido Univ., (2002.) 19: 190-250.

-_- and K. Hayashida 1958. Biology of the primitive social bee Halictus duplex Dalla Torre. I. Preliminary report on the general life history. Annot.Zool. Japan, 31: 151-155.

- and - - 1960. Ditto, II. Nest structure and immature stages. Ins. Sociaux 7: 5798.

and 1961. Ditto, III. Activities in spring solitary phase. J. Fac. Sci., Hokkaido Univ., (Zool.), 14: 639-682.

-- - and -- 1968. Bionomics and sociology of summer matrifilial phase in the social halictine bee, Lasioglossum duplex. J. Fac. Sci., Hokkaido Univ., (Zool.) 16: 413-513.

- and C. D. Michener 1962. The nest architecture of the sweat bees. A comparative study of behavior. 135 pp. Univ. Kansas Press, Lawrence.

- and J. S. Moure 1965. Cephalic polymorphism in some Neotropical halictine bees (Hymenoptera-Apoidea). Anais Acad. Bras. Ciênc. 37 :303-313.

- - and M. Munakata 1972.. Distribution and bionomics of a Transpalaearctic eusocial halictine bee, Lasioglossum (Evylaeus) calceatum, in northern Japan, with reference to its solitary life cycle at high altitude. J.Fac. Sci., Hokkaido Univ., (Zool.) 18: 411-439.

-_ and F. L. Wain 1966. Halictus latisignatus Cameron : A polymorphic Indian halictine bee with caste differenciation (Hymenoptera, Halictidae). J. Bombay Nat. Hist. Soc. 63: 57-73.

Utida, S. 1957. Development zero temperature in insect. Jap. J. Appl. Ent. Zool. 1 : 46-53. (In Japanese with English summary) 